\title{
Практика земельного передела 1917-1920 гг. и его последствия (на примере Данковского уезда Рязанской губернии)*
}

\author{
Э.В. Гатилов \\ Липецкий государственный технический университет (ЛГТУ), \\ Россия, 398600, Липецк, Московская, 30 \\ E-mail: gatilow.e@yandex.ru
}

\begin{abstract}
Аннотация. Земля как ведущий ресурс хозяйственной деятельности сформировала к себе определенное отношение со стороны крестьянства. Это отношение, оформившееся в начале XX столетия в устойчивое желание к ликвидации частновладельческой собственности на землю, наиболее остро проявлялось в земледельческой массе малоземельного черноземного центра России в период Первой мировой войны и вылилось с Февральской революцией 1917 г. в открытое захватное движение. Хаотичный передел 1917 г. попытались поставить под контроль земельные органы новой большевистской власти. Проведение земельного передела в черноземном регионе в течение 1917-1920 гг. не привело к существенным изменениям параметров хозяйственной деятельности крестьянства, но, напротив, усугубило и законсервировало прежние проблемы деревни. В данной статье ставится целью на основе архивных материалов по Данковскому уезду Рязанской губернии проследить ход земельного передела в провинциальном уезде и крестьянскую рефлексию на данный процесс. Вводимые в оборот новые документы конфликтных комиссий уездного земельного отдела раскрывают содержательную часть крестьянской реакции на ход аграрных трансформаций. Методологической основой настоящего исследования является принцип историзма, сравнительный и статистический анализы, контент-анализ.
\end{abstract}

Ключевые слова: Данковский уезд, передел земли, крестьянская рефлексия, поземельный конфликт.

Для цитирования: Гатилов Э.В. 2020. Практика земельного передела 1917-1920 гг. и его последствия (на примере Данковского уезда Рязанской губернии). Via in tempore. История. Политология, 47 (3): 567-579. DOI 10.18413/2687-0967-2020-47-3-568-579.

\section{The practice of land redistribution in 1917-1920 and its consequences (on the example of Dankov county of Ryazan province)}

\author{
Eduard V. Gatilov \\ Lipetsk State Technical University, \\ 30 Moskovskaya St., Lipetsk, 398600, Russia \\ E-mail: gatilow.e@yandex.ru
}

\begin{abstract}
The land, as a leading resource of economic activity, has formed a certain attitude to itself from the peasants. This attitude, formed at the beginning of the twentieth century in a steady desire to eliminate private ownership of land, most acutely manifested in the agricultural mass of the small Chernozem center of Russia during the First World War and resulted with the February Revolution of 1917 in an open seizure movement. Chaotic redistribution in 1917 tried to put the land authorities of the new Bolshevik government under control. Conducting land redistribution in the Chernozem region during 1917-1920 did not lead to significant changes in the parameters of economic activity of the peasants, but,

* Исследование выполнено при финансовой поддержке фонда РФФИ в рамках научного проекта № 19-09-00061 А «Поземельные конфликты начального советского периода как индикатор трансформации крестьянской идентичности (1917-1920 гг.)».
\end{abstract}


on the contrary, exacerbated and preserved the previous problems of the village. This article aims to trace the course of land redistribution in the provincial district and peasant reflection on this process on the basis of archival materials on the Dankovsky uyezd (county) of the Ryazan province. The new documents of the conflict commissions of the district land Department that are being put into circulation reveal the content of the peasant reaction to the course of agrarian transformations. The methodological basis of this research is the principle of historicism, comparative and statistical analyses, and content analysis.

Key words: Dankov uyezd (county), land redistribution, peasant reflection, land conflict.

For citation: Gatilov E.V. 2020. The practice of land redistribution in 1917-1920 and its consequences (on the example of Dankov county of Ryazan province). Via in tempore. History and political science, 47 (3): 567-579 (in Russian). DOI 10.18413/2687-0967-2020-47-3-568-579.

Вопросы аграрного кризиса в России и на территории ее Черноземного центра начала XX в. неоднократно рассматривались в отечественной историографии [Слепнёв, 2006; Чуркин, 2006, 2016; Есиков, 2007; Перепелицын, Фурсов, 2008; Есикова, 2009; Кудинова, 2011; Николашин, 2013, 2019; Карпачев, 2014, 2016; Колупаев, 2015; Перепелицын, 2015; Безгин, 2017; Ларина, Трусова, 2017; Беспалов, 2018; Гатилов, Николашин, 2019]. Но, как совершенно справедливо замечает Н.А. Жиров, «за десятилетия исследований было выпущено немало трудов, хотя и ощущается недостаточная изученность микроисторических сюжетов» [Жиров, 2017, 99]. Исходя из этого в данной статье основное внимание обращено на проведение земельного передела в 1917-1920 гг. на территории Данковского уезда Рязанской губернии и на его социокультурные последствия. Данковский уезд располагался в южной части губернии и считался по почвенным качествам одним из самых плодородных, что обуславливало высокую значимость земледелия в жизни местного населения. Крестьянская рефлексия на проводимые аграрные изменения раскрывает не только отношение к ним, но и психологию, состояние самого земледельческого слоя.

Практика земельного передела была инициирована на территории Данковского уезда событиями Февральской революции 1917 г. и начала осуществляться в виде захвата частновладельческих и, прежде всего, помещичьих земель. По данным Всероссийской сельскохозяйственной и поземельной переписи 1917 г., на территории уезда числилось частновладельческими 106 хозяйств с 25 933,7 дес. пашни, в то время как хозяйств крестьянского типа числилось 21239 с 140 578,8 дес. пашни [Поуездные итоги]. Фактически частновладельческий фонд, по материалам переписи, составлял 15,5 \% от всего пахотного фонда уезда. В условиях растущей крестьянской агрессии часть помещиков самовольно отказалась от своих имений (за 5 месяцев своего существования Данковский уездный земельный комитет принял на учет 20 имений ${ }^{98}$ ), часть - только от отдельных своих земель: так, двое помещиков в Змиевской волости отказались от земли в количестве 14 и 5 десятин ${ }^{99}$.

Захватное движение крестьян активизировалось в конце лета - осенью 1917 г. в связи с необходимостью подготовки к яровому севу 1918 г. Объектом внимания данковского крестьянства стали частновладельческие земли, как помещичьи, так и других владельцев. К примеру, крестьяне общества села Змиева Змиевской волости «нахальным образом и чуть ли не с угрозой завладели собственностью - пахотной полевой землей» двух хуторян ${ }^{100} .3$ сентября 1917 г. граждане села Избищи Ягодновской волости в количестве 140 домохозяев имели суждение между собой о недостатке земли на 1918 г. и просили уездный земельный комитет разрешить запахать землю в количестве 80 десятин, числившихся за Крестьянским Рязанским поземельным банком ${ }^{101}$. Аналогичным образом

${ }^{98}$ Областное казенное учреждение «Государственный архив Липецкой области» (далее - ОКУ ГА-

ЛО). Ф. Р-448. Оп. 1. Д. 4. Л. 58.

${ }^{99}$ ОКУ ГАЛО. Ф. 1612. Оп. 1. Д. 5. Л. 8-9.

100 Там же. Л. 2.

${ }^{101}$ Там же. Д. 1. Л. 1. 
16 сентября 1917 г. Гурьевское и Мещаковское общества села Березовки Еропкинской волости выступили с ходатайством перед волостной земельной управой о передаче им в арендное пользование 243 десятин из земель частного владельца Демидова под яровой посев ${ }^{102}$. Отсутствие или удаленность помещичьих имений и земель от крестьянских поселений ставили земледельцев перед необходимостью поиска допустимых для раздела территорий. Граждане д. Репец Острокаменской волости в первой половине октября 1917 г., например, заявили в адрес волостной земельной управы: «за нашим обществом имеется всего пахотной земли 180 дес., а всех нас 30 домохозяев, и земли для нас совершенно мало, арендовать землю нам не у кого, так как землевладельцев, расположенных возле нас, нет, но есть лишь земля в наших дачах, принадлежащая гражданам д. Котовских, ... а всего 132 дес., и эту землю мы бы желали взять в свое арендное пользование, т. к. граждане других волостей не имеют права пользования землей, которая находится в наших дачах, а мы как малоземельные желаем такой воспользоваться и арендой платить» ${ }^{103}$. В волостях, где были помещичьи земли, создавались условия для их первостепенного распределения.

Приход к власти большевиков сопровождался удовлетворением давних чаяний крестьянства - ликвидацией частной собственности на землю и передачей последней в ведение крестьянства, несмотря на то, что подобная передача, как и уравнительное землепользование, не входили изначально в их планы. Однако последствия нового земельного передела оказались не столь очевидными, как они виделись основной массе земледельцев.

Весной 1918 г. в Данковском уезде, по данным уездного земельного комитета, всей земли значилось 228 787,5 дес., в т. ч. под усадьбой - 8180 дес.; луга занимали 6867 дес., выгоны - 5110 дес., леса - 7 775,6 дес., неудобные земли включали 6171 десятин. Из всего массива уезда пахотные земли составляли 194 683,9 десятины, практически 85 \% от площади уезда. При этом население уезда исчислялось в 139850 душ ${ }^{104}$. Уточненные данные июня 1918 г. дали 225 049,6 дес. всей земли при 192 298,9 дес. пашни и 150988 душах ${ }^{105}$. Сводные данные волземкомов на конец 1918 г. свидетельствуют о наличии в уезде 109 886,5 дес. пахотной надельной земли и 79 256,5 дес. пахотной частновладельческой (далее - ч/в). Фактически земли, отнесенные к частным в массиве пахотных земель уезда, составляли уже 42 \% против 15,5 \% по данным переписи 1917 г.

Учет земель частных владельцев определил разделение волостей на много- и малоземельные. Практически все волости Данковского уезда были малоземельными. Использование определений «малоземельные» и «многоземельные» характеризовало наличие частновладельческих земель, которые на уравнительной основе можно было разделить между земледельцами. Если в волости средняя подушевая норма выполнялась за счет надельных и частных земель и оставался какой-то остаток последних, то он предназначался для наделения других, как правило, близлежащих волостей.

Рязанский губернский съезд земельных отделов 23 марта 1918 г., учитывая требования большинства крестьянских наказов, определил, что передел под яровой посев 1918 г. должен совершаться по живым душам и независимо от пола и возраста ${ }^{106}$. Решением очередного съезда Данковского уездного земельного комитета от 5 апреля 1918 г. были определены площади межволостного перераспределения бывших частных земель под яровой посев 1918 г. - рисунок 1.

Согласно представленным данным, площадь частновладельческого фонда, предназначенного для перераспределения под ярь 1918 г., исчислялась в размере 6459 дес., что составляло приблизительно 3,5 \% от всех пахотных земель уезда и 8,2 \% ч/в фонда.

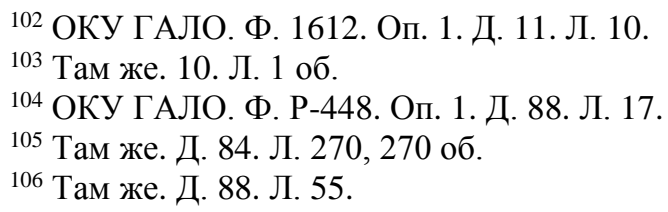




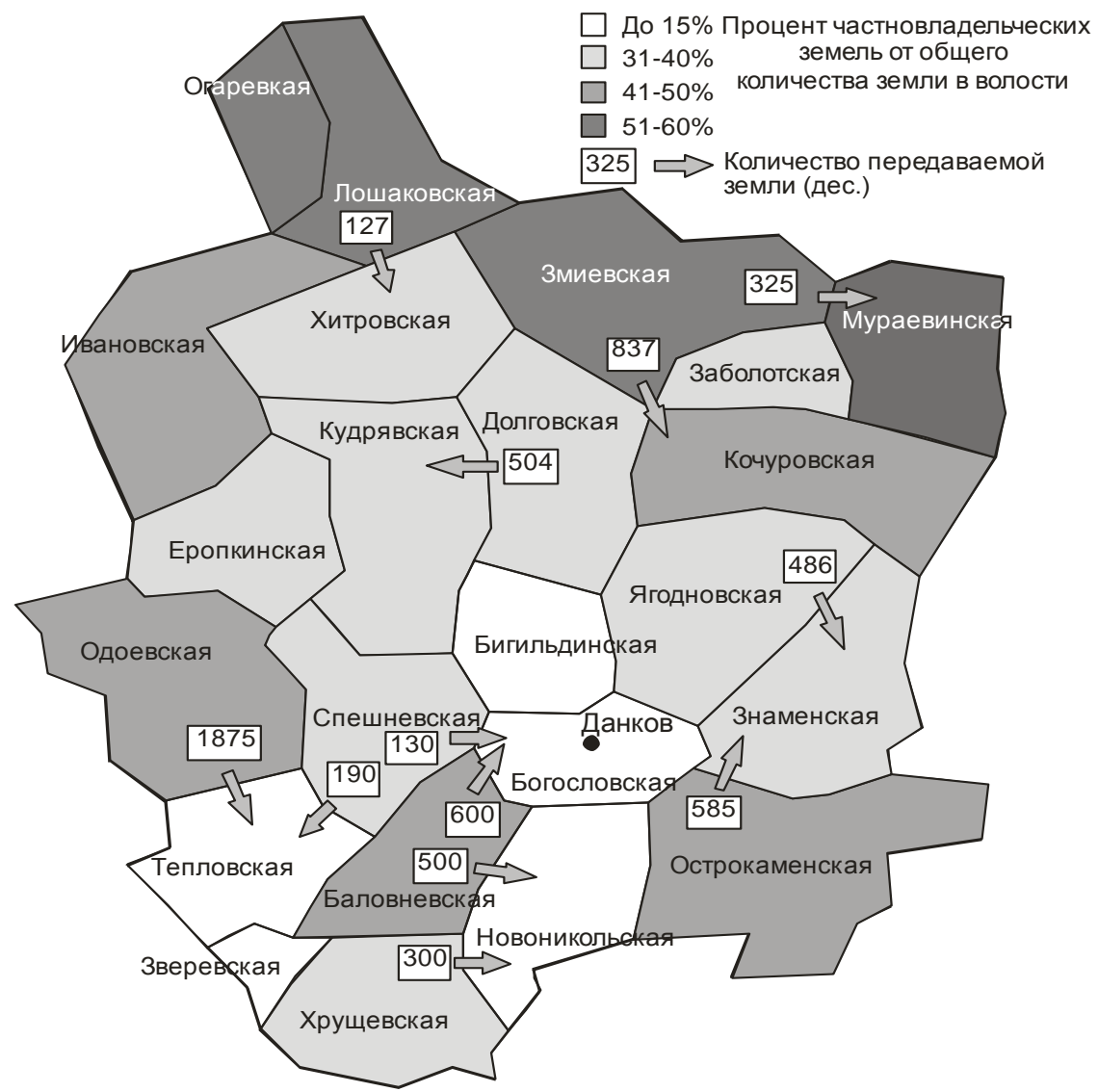

Рис. 1. Проект межволостного перераспределения частновладельческих земель Данковского уезда под яровой посев 1918 г. (в дес.) ${ }^{107}$

Fig. 1. The project of inter-western redistribution of private land in Dankov county under spring sowing in 1918 (in tens)

В волостях бывшие частные земли использовались для разверстки по душевой норме между местными сельскими обществами. Восемь волостей для выполнения нормы наделения не имели наличного фонда ч/в земель и должны были получить их в 9-ти волостях, где оказался достаточно большой объем экспроприированных помещичьих и прочих земель. Реально к первой категории относились лишь 5 волостей с низким процентом частновладельческих площадей в массиве волости: Зверевская (1\%), Бигильдинская (6 \%), Богословская (10\%), Новоникольская (11\%) и Тепловская $(12 \%)$. Наделяемая для выполнения нормы Знаменская волость имела $39 \%$ ч/в земель, Хитровская и Кудрявская - по $40 \%$, Кочуровская - $46 \%$, а в Мураевинской волости $56 \%$ земель были отнесены к частновладельческим. При разверстке этих земель основная проблема состояла в количественном росте населения. Как указано выше, численность учтенного земледельческого населения в уезде только в первой половине 1918 г. возросла с 139850 до 150988 душ, то есть на 11138 человек. Даже если принять во внимание несомненное завышение данных, представляемых волземкомами, следует констатировать существенное увеличение в уезде лиц, имевших право на получение земли для обработки.

Помимо невозможности уравнительно и удобно распределить земли между сельскими обществами и прочими хозяйствующими субъектами уезда, подвижность численности населения стала дополнительным фактором сезонных переделов земельного фонда волостей. Поволостные данные позволяют проследить масштабы сезонных переделов в течение 1918-1919 гг., а именно передел под яровой посев 1918 г., озимый посев 1918 г. и яровой посев 1919 г. На рисунке 2 эти данные по волостям представлены последовательно, напри- 
мер, земли, выделенные в Одоевской волости для Зверевской под указанные посевы, составили 78, 50 и 650 десятин. Одинаковые данные, например, 48,48 и 48 десятин, выделенные в Еропкинской волости для Кудрявской, свидетельствуют о фактическом закреплении участка в 48 дес. за кудрявскими крестьянами в массиве еропкинских земель.

Представленные материалы не отражают всей полноты и противоречивости земельного передела 1918-1919 гг. Желание воплотить в проводимом переделе принцип социальной справедливости, выразившийся в уравнительном распределении, привел к тому, что наделение протекало лоскутно, из земель, находившихся прежде в руках разных собственников и на разных территориях. Это, в частности, видно на примере Хрущевской волости. По волостным данным всей земли в пределах Хрущевской волости насчитывалось 9695 дес. Из данного массива, согласно постановлению Данковского УЗК от 5 апреля 1918 г., 200 дес. должны были перейти в пользование граждан с. Перехвали Новоникольской волости, что отражено на рисунке 2.

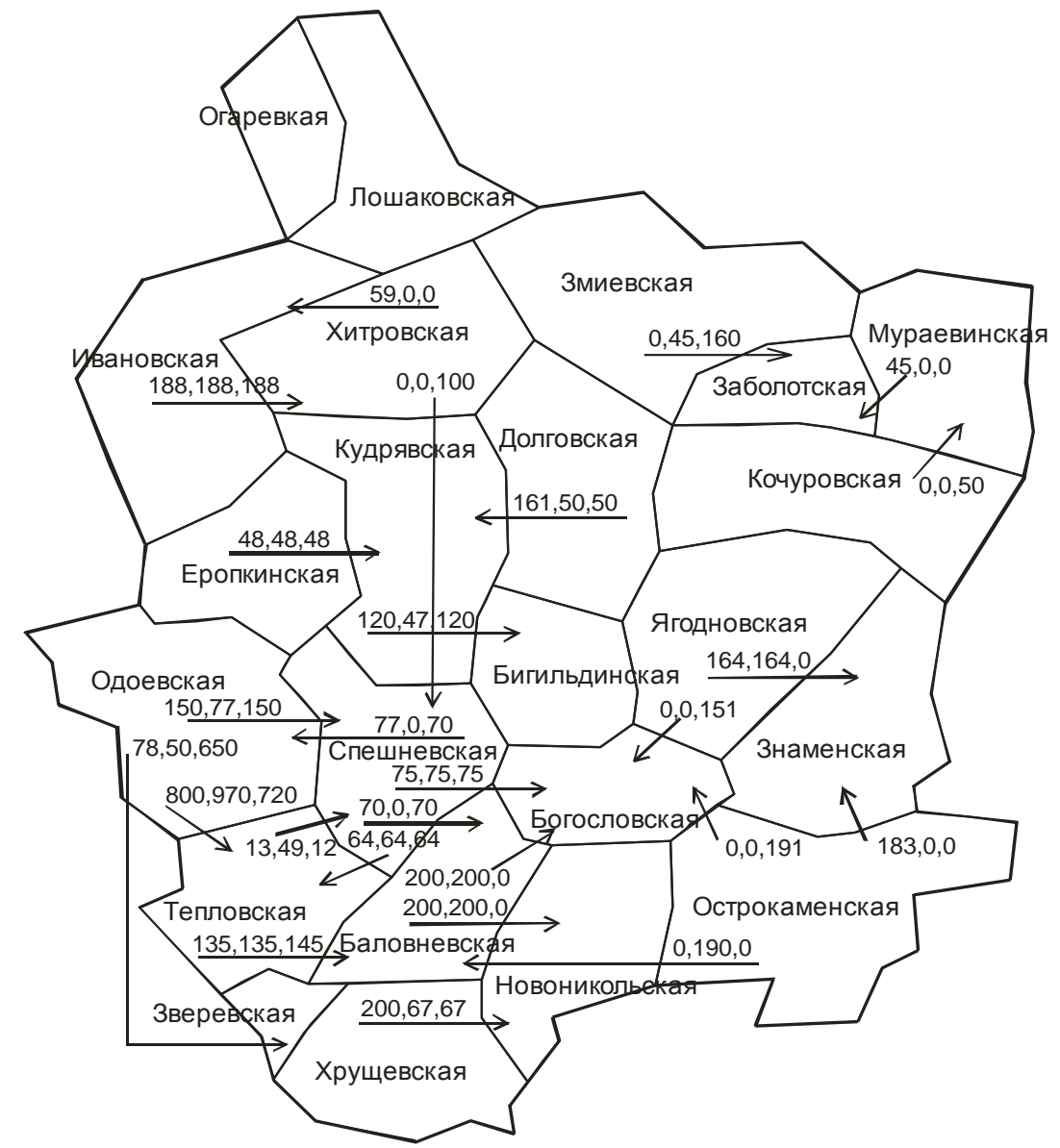

Рис. 2. Земельные площади, выделенные в волостях-донорах для волостей-реципиентов под посевы 1918-1919 гг. (в дес.) ${ }^{108}$

Fig. 2. Land areas allocated in the donor parishes for the recipient parishes for sowings 1918-1919 (in tens)

Непосредственно распределению в Хрущевской волости как надельной, так и частновладельческой подлежало 9495 десятин земли. Учитывая, что население обоего пола на момент весеннего передела составляло 9127 душ, то на душу приходилось 1,04 дес. или 1 дес. 96 кв. саж., но так как точного количества земли еще не было установлено, то в расчет была принята норма не в 1,04, а в 1,03 дес., то есть 1 дес. 72 кв. сажени. Наделение происходило из всех доступных в волости частновладельческих земель. Размеры выделенных поселенно земель представлены в таблице $1{ }^{109}$. 
Распределение земли между сельскими обществами Хрущевской волости под яровой посев 1918 г. Distribution of land between rural societies of the Khrushchevskaya parish under spring sowing in 1918

\begin{tabular}{|c|c|c|c|c|}
\hline & с. Хрущово 1 & с. Хрущово 2 & д. Хорошовка & д. Ларионовка \\
\hline Количество душ & 2100 & 394 & 1378 & 627 \\
\hline Причитается земли & 2163 & 406 & 1419 & 646 \\
\hline Надельной & 1175 & 220 & 993 & 391 \\
\hline Недостаток & 988 & 186 & 426 & 250 \\
\hline $\begin{array}{l}\text { Покрыть недоста- } \\
\text { ток из }\end{array}$ & $\begin{array}{l}\text { Имения Игна- } \\
\text { тьевой } \\
575 \text { дес. } \\
\text { Причта } \\
\text { с. Хрущево - } \\
36 \text { дес. } \\
\text { Им. Стаховича } \\
\text { при с. Спешне- } \\
\text { ве и Надежди- } \\
\text { ной - } 377 \text { дес. }\end{array}$ & $\begin{array}{l}\text { Им. Хомякова } \\
\text { при с. Хруще- } \\
\text { во - } 186 \text { дес. }\end{array}$ & $\begin{array}{l}\text { Причта с. Хо- } \\
\text { рошовка } \\
252 \text { дес. } \\
\text { Им. Стаховича } \\
\text { при д. Надеж- } \\
\text { диной } \\
138 \text { дес. }\end{array}$ & $\begin{array}{l}\text { Им. Хомякова при } \\
\text { с. Хрущево - } 98 \text { дес. } \\
\text { Им. Скворцова при } \\
\text { с. Хрущево. }-136 \text { дес. } \\
\text { Им. Мазуриной при } \\
\text { д. Ларионовке - } 6 \text { дес. } \\
\text { Им. Стаховича при } \\
\text { д. Секирино - } 15 \text { дес. }\end{array}$ \\
\hline & с. Спешнево & д. Погореловка & д. Надеждино & с. Телепнево \\
\hline Количество душ & 591 & 434 & 370 & 3233 \\
\hline Причитается земли & 608 & 447 & 381 & 3330 \\
\hline Надельной & 598 & 366 & 290 & 2198 \\
\hline Недостаток & 10 & 81 & 91 & 412 \\
\hline $\begin{array}{l}\text { Покрыть недоста- } \\
\text { ток из }\end{array}$ & $\begin{array}{l}\text { Им. Шишкова } \\
\text { при с. Спешне- } \\
\text { ве - } 10 \text { дес. }\end{array}$ & $\begin{array}{l}\text { Причта } \\
\text { с. Спешнева - } \\
36 \text { дес. } \\
\text { Им. Стаховича } \\
\text { при с. Спеш- } \\
\text { неве - } 45 \text { дес. }\end{array}$ & $\begin{array}{l}\text { Им. Стаховича } \\
\text { при д. Надеж- } \\
\text { диной }-91 \text { дес. }\end{array}$ & $\begin{array}{l}\text { Причта с. Телепнева - } \\
36 \text { дес. Им. Хомякова } \\
\text { при с. Хрущево } \\
49 \text { дес. } \\
\text { Им. Шишкова при } \\
\text { д. Хорошовке - } 327 \text { дес. }\end{array}$ \\
\hline
\end{tabular}

Табличные примеры подтверждают лоскутность земельной компенсации, проводимой за счет частных земель, в данном случае помещичьей и церковной. Этим усугублялись старые проблемы черноземной деревни - черезполосность, дальнеполосность, которые были одним из бедствий крестьянских обществ еще в дооктябрьский период. Да и малоземелье преодолеть не удалось. Показатели на душу населения по сезонным переделам в Данковском уезде представлены в таблице 2. Волости размещены в таблице в зависимости от географического положения - с севера на юг. Из-за отсутствия данных по Змиевской, Мураевинской, Еропкинской, Бигильдинской и Тепловской волостям последние не включены в таблицу.

Сравнительный анализ приведенных данных позволяет заключить, что только в четырех волостях - Огаревской, Ивановской, Долговской и Острокаменской норма наделения осталась неизменной. Ряд волостей характеризует несущественное изменение показателей, а в отношении шести волостей - Кудрявской, Кочуровской, Ягодновской, Знаменской, Одоевской и Спешневской - отмечается устойчивое снижение нормы наделения. Таким образом, в рамках трехполья данковские земледельцы в среднем увеличили свои наделы в диапазоне от 0,9 до 1,5 дес. Только в Хрущевской волости этот показатель достиг 1,94 дес. Данные по Хитровской и Зверевской волостям демонстрируют минимальное прирезание земли от 6 до 12 саж. на душу. 
Средняя норма наделения землей на душу населения волости (в дес.) ${ }^{110}$ Average land allocation per capita of the parish (in tens)

\begin{tabular}{|l|l|c|c|c|}
\hline \multirow{2}{*}{ № п/п } & \multirow{2}{*}{ Волость } & \multicolumn{2}{|c|}{1918 г. } & Озимое (дес.) \\
\cline { 3 - 5 } & & Яровое (дес.) & Яровое (дес.) \\
\hline 1. & Огаревская & 0,50 & 0,50 & 0,50 \\
\hline 2. & Лошаковская & 0,44 & 0,42 & 0,42 \\
\hline 3. & Хитровская & 0,004 & 0,005 & 0,005 \\
\hline 4. & Ивановская & 0,46 & 0,46 & 0,46 \\
\hline 5. & Заболотская & 0,33 & 0,33 & 0,40 \\
\hline 6. & Долговская & 0,45 & 0,45 & 0,45 \\
\hline 7. & Кудрявская & 0,43 & 0,40 & 0,38 \\
\hline 8. & Кочуровская & 0,46 & 0,43 & 0,41 \\
\hline 9. & Ягодновская & 0,50 & 0,40 & 0,40 \\
\hline 10. & Знаменская & 0,45 & 0,42 & 0,40 \\
\hline 11. & Одоевская & 0,47 & 0,40 & 0,39 \\
\hline 12. & Спешневская & 0,31 & 0,30 & 0,27 \\
\hline 13. & Богословская & 0,30 & 0,30 & 0,31 \\
\hline 14. & Баловневская & 0,31 & 0,32 & 0,33 \\
\hline 15. & Острокаменская & 0,47 & 0,47 & 0,47 \\
\hline 16. & Новоникольская & 0,41 & 0,33 & 0,44 \\
\hline 17. & Зверевская & 0,003 & 0,003 & 0,003 \\
\hline 18. & Хрущевская & 1,00 & 0 & 0,94 \\
\hline
\end{tabular}

Результаты контент-анализа оценок подобного перераспределения земли, зафиксированных земельными отделами волостных советов в конце 1918 г., ${ }^{111}$ приведены в таблице 3.

Оценивая заключения волземотделов как положительные или отрицательные, можно констатировать, что доминирующий в оценках негатив в отношении проведенных перераспределений говорит о небольшом земельном приращении. Положительные оценки связаны как правило с теми волостями, в которых произошли незначительные межволостные передвижки (рисунок 2), несущественно изменившие внутриволостной земельный порядок.

Таким образом, справедливое с точки зрения крестьянства уравнительное перераспределение частновладельческих земель не ликвидировало основных проблем данковской деревни, но, напротив, увеличило внутреннюю конфликтность как между отдельными селениями, так и между волостями.

Крестьянским обществам, получавшим прибавку земли в массиве своей волости, необходимо было урегулировать вопросы доступности к выделенным землям с местными селениями, что не всегда находило их понимание и сопровождалось межселенными конфликтами. Обществам, получившим прибавку в массиве других волостей, необходимо было наладить обработку удаленных территорий, которые местным населением рассматривались как свои. Удаленность земель, настрой местного населения, а нередко и самовольная обработка ими участков, назначенных селениям других волостей, создавали серьезные трения между крестьянскими обществами, приобретающие характер межволостных поземельных конфликтов. В этих условиях волости, оставшиеся в своих границах, на «собственных» частновладельческих землях имели меньше оснований для подобных споров. Однако приток населения в деревню, обусловивший, в частности, сезонные перераспределения, усугублял сложившееся положение. При этом можно предположить, что прибывающее в сельскую местность население группировалось в инфраструктурно удобных волостях, т. е. наиболее близких к уездному

${ }^{110}$ ОКУ ГАЛО. ОП. 1. Д. 137. Л. 139-163.

111 ОКУ ГАЛО. ОП. 1. Д. 137. Л. 139-163. 
центру - г. Данкову - Богословской, Бигильдинской, Новоникольской, создавая в них наибольшие проблемы при разверстке земли и увеличивая конфликтность.

Заключения о состоянии населения волостных земельных отделов Данковского уезда Conclusions on the condition of the population of the Dankov County land parishes

\begin{tabular}{|c|c|c|c|}
\hline Волость & Состояние населения в оценках волземотделов & $\begin{array}{r}\text { Пол } \\
\text { отр } \\
\end{array}$ & ная/ \\
\hline Огаревская & $\begin{array}{l}\text { Распределение земли на хозяйства отразилось благоприят- } \\
\text { но, и население этим удовлетворилось }\end{array}$ & + & \\
\hline Хитровская & Население удовлетворено без всякого ропота & + & \\
\hline Ивановская & $\begin{array}{l}\text { Наделение жителей по распределении земли удовлетвори- } \\
\text { тельно }\end{array}$ & + & \\
\hline Мураевинская & $\begin{array}{l}\text { Ежегодный раздел тормозит вывоз навоза, население выра- } \\
\text { жает желание повысить на 5-6 лет }\end{array}$ & & - \\
\hline Заболотская & $\begin{array}{l}\text { Хозяйство от распределения не пострадало, население рату- } \\
\text { ет на малоземелье }\end{array}$ & + & - \\
\hline Долговская & $\begin{array}{l}\text { Распределение земли в хозяйствах отразилось в недостаточ- } \\
\text { ном количестве. }\end{array}$ & & - \\
\hline Кудрявская & $\begin{array}{l}\text { Распределение земли на хозяйстве отразилось благоприят- } \\
\text { но, но удовлетворено не в достаточной мере }\end{array}$ & + & - \\
\hline Кочуровская & $\begin{array}{l}\text { Население осталось частью по одиночке наделением земли } \\
\text { неудовлетворительно в волости }\end{array}$ & & - \\
\hline Ягодновская & $\begin{array}{l}\text { Распределение земли на строе хозяйства отразилось удовле- } \\
\text { творительно }\end{array}$ & + & \\
\hline Знаменская & Население волости неудовлетворено, ощущается недостаток & & - \\
\hline Одоевская & $\begin{array}{l}\text { При распределении земли между обществами на строе хозяй- } \\
\text { ства отразилось неудовлетворительно, т. к. трудовые хозяй- } \\
\text { ства оказались малоземельными, получившие много земли не } \\
\text { имеют для обработки ее рабочего скота и с/х инвентаря }\end{array}$ & & - \\
\hline Баловневская & $\begin{array}{l}\text { Население недовольно разверсткой УЗО, т. к. этой земли } \\
\text { недостаточно для устроения сельского хозяйства }\end{array}$ & & - \\
\hline Зверевская & $\begin{array}{l}\text { Распределение земли обошлось без расстройства хозяйства } \\
\text { и население осталось удовлетворительным }\end{array}$ & + & \\
\hline Хрущевская & $\begin{array}{l}\text { Хозяйство несколько улучшилось, население же не вполне } \\
\text { удовлетворено }\end{array}$ & & - \\
\hline
\end{tabular}

Для того чтобы ответить на вопрос, насколько аграрное реформирование повлияло на уровень крестьянской конфликтности, проведем статистический анализ показателей ряда конфликтов, имевших место в данковской деревне в 1918-1920 гг. Основным источником выступают материалы Конфликтной комиссии при земельном отделе Данковского уезда. К анализу привлечено 36 конфликтов ${ }^{112}$. В качестве предмета анализа выступали четыре категории: причины конфликта, уровни конфликта, предмет и параметры конфликта. В качестве ведущих причин конфликтов выделены три: разверстка земли, право пользования и самовольный захват. Субъектами конфликтов выступают представители крестьянских хозяйств, селения, волости. По субъектам выделены следующие уровни конфликтов: межкрестьянский (непосредственно между отдельными крестьянами), внутриселенный (между отдельными крестьянами и крестьянским обществом одного селения), межселенный (внутриволостной) и межволостной. В качестве предмета конфликтов выде-

${ }^{112}$ ОКУ ГАЛО. Оп. 1. Д. 80, 87, 140, 144, 146, 148, 149, 165, 167, 168, 170, 171, 172, 173, 174, 175 , 176, 177, 178, 179, 180, 182, 183, 185, 186, 187, 188, 269, 277. 
лены следующие: земля, урожай и иные объекты (сад, сенокос, пруд, разработка камня). Категория «параметры конфликта» охватывает три элемента: расположение (дальний близкий, черезполосный, в границах дачи селения и т. д.), традиции пользования (пользование ранее купленной или арендованной землей, или иным объектом, справедливость пользования), трудовые усилия (труд, вложенный в тот или иной объект). Анализируемые данные представлены в процентном отношении (рисунок 3 ).

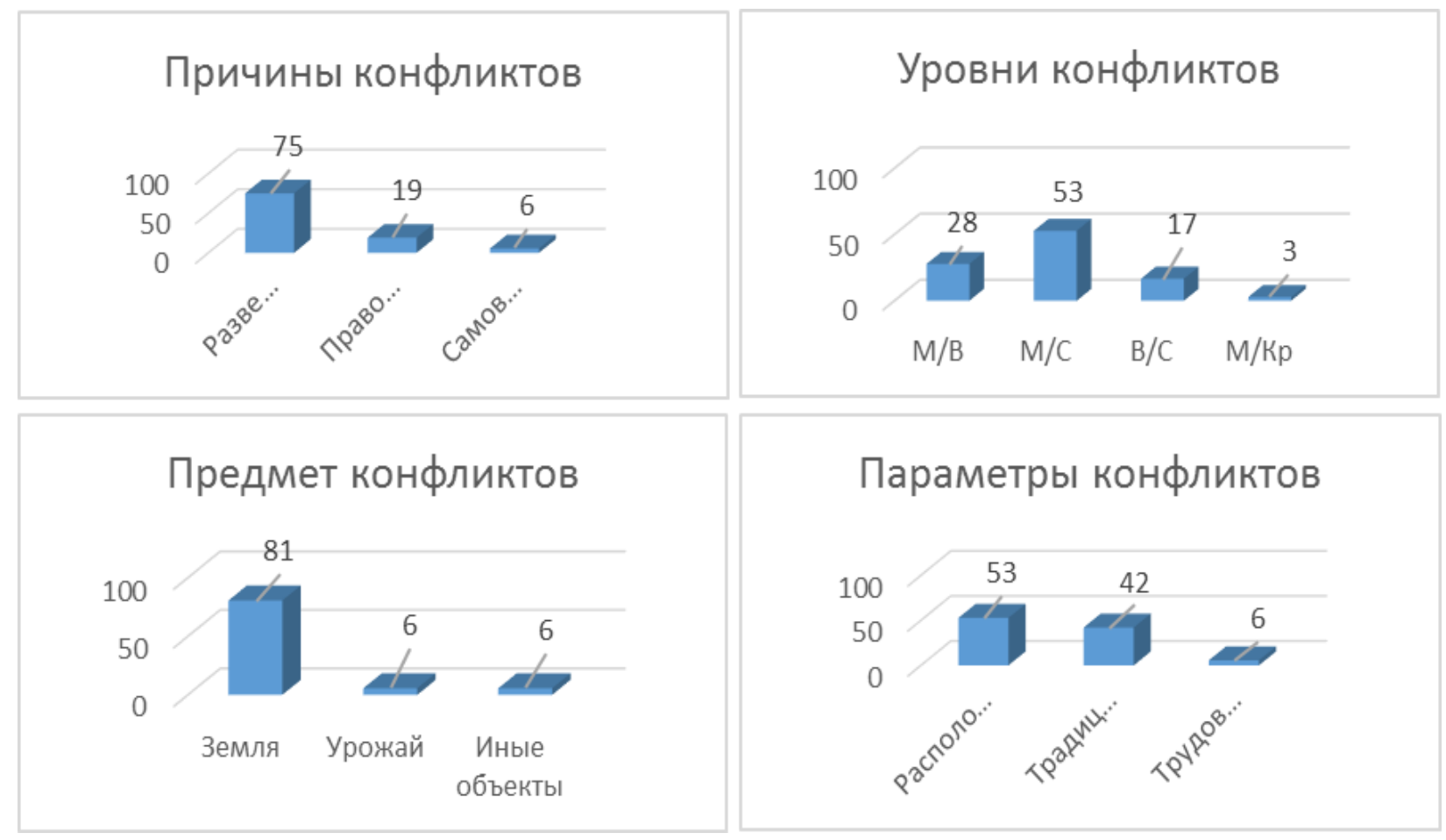

Рис. 3. Категории анализа конфликтов Данковского уезда 1918-1920 гг. (в \% \%)

Fig. 3. Categories of analysis of conflicts in Dankov county in 1918-1920 (in \%)

Анализ представленных на рисунке 3 категорий конфликта позволяет заключить, что именно земля как основа крестьянского хозяйства черноземной полосы стала камнем преткновения в проводимом переделе - более 80 \% конфликтов связано с ней. Среди причин конфликтов доминирующей была проводимая большевиками разверстка земли. Будучи согласными с необходимостью долгожданного введения в крестьянский оборот частновладельческих земель, с установлением средней нормы наделения как реализацией принципа уравнительного распределения, земледельцы оказались неготовыми к инфраструктурным изменениям - нахождению переданных им земель на территории других волостей, дальноземелью, черезполосице. Фактически два параметра определяли недовольство крестьян - местоположение передаваемого селению земельного массива и изменение традиций пользования землей. В большинстве случаев ранее купленные или арендованные земли рассматривались земледельцами как свои, их переход в пользование других селений вызывал недоумение, недовольство и нередко выливался в конфликт. Обращает на себя внимание, что межселенный конфликт стал ведущим. Селения, даже в рамках одного сельского общества, выступали противоборствующими сторонами в большинстве рассмотренных случаев - 53 \%, что ставит вопрос о специфичности воссозданной в изучаемый период общине. Межволостной конфликт $28 \%$ - фактически являлся продолжением межселенного, где конфликтовали, как правило, селения смежных волостей, реже волземотделы как представители неудовлетворенных селений. На этом фоне конфликты внутри селений или между отдельными крестьянскими хозяйствами становились второстепенными, о чем свидетельствует их низкий процент в анализируемой совокупности - 17 и $3 \%$ соответственно. 
Следует заметить, что практика земельного передела, реализуемая большевиками, оказалась типичной для черноземных территорий. Но не типичными оказались реакции земледельцев в региональном преломлении - от пассивного принятия до активного противодействия, что объясняется целым набором факторов, анализ которых выходит за рамки настоящей статьи.

Таким образом, практическое воплощение крестьянской мечты «о землице» оказалось далеким от массовой иллюзии. Ликвидация частновладельческой собственности на землю практически не повлияла на хозяйственный уклад основной массы данковских земледельцев. Крестьяне не получили всей земли - ее часть стала основанием для создания новых, коллективных форм хозяйствования. В то же время в деревню вернулось значительное количество «бывших» крестьян, что обострило отношения по линии «свой» - «чужой». Социокультурный разрыв - несоответствие долго бытовавшего представления с одной стороны и мало изменившихся в лучшую сторону условий хозяйственной деятельности - с другой стороны, создали атмосферу неудовлетворенности. Проводимая в условиях гражданской войны аграрная политика все больше консервировала старые проблемы деревни и поляризовала отношения внутри самого крестьянства. Показателен в этой связи следующий пример. 18 апреля 1920 г. в Данковский уездный комитет РКП(б) обратился бывший красный офицер Иванов М.Н. с просьбой оказать помощь в получении надельной земли. По факту он, придя из армии, не попал в разверстку, и общество с. Одоевщино Одоевской волости отказалось наделять его из уже распределенной надельной, предложив взамен землю в 7 верстах из экономической. Иванов увидел в данном решении происки кулачества. Его обращение в Данковский УЗО и принятое предписание воздействия на одоевское общество не возымели, почему он и вынужден был продолжить защиту своих интересов уже в уездном комитете РКП(б) ${ }^{113}$. Данный пример свидетельствует, что данковское крестьянство и в 1920 г. продолжало жить по прежним мирским законам. Консерватизм данковской деревни станет главным препятствием на пути последующих аграрных преобразований на территории уезда.

\section{Список литературы}

1. Безгин В.Б. 2017. Крестьянский «мір» в революции 1917 года (на материалах Тамбовской губернии). Ежегодник по аграрной истории Восточной Европы. 1: 160-168.

2. Беспалов С.В. 2018. Аграрный кризис в России конца XIX века: внешне- и внутриэкономическое измерения. Общество и власть в императорской России, СССР и современной Российской Федерации: 297-309.

3. Гатилов Э.В., Николашин В.П. 2019. Поземельные конфликты Черноземья начального советского периода 1917-1920 гг. Клио. 2019. 12 (156): 104-121.

4. Есиков С.А. 2007. Крестьянское землевладение и землепользование в Тамбовской губернии в пореформенное время (1861-1905 гг.). Историко-правовое исследование. СПб., Нестор, 189.

5. Есикова М.М. 2009. Аграрный кризис конца XIX - начала XX века. Вестник Саратовского государственного социально-экономического университета. 3 (27): 230-233.

6. Жиров Н.А. 2017. Крестьянское землевладение в Орловской губернии на рубеже XIX-XX вв. Ежегодник по аграрной истории Восточной Европы. 1: 99-104.

7. Карпачев М.Д. 2014. Финансовые повинности крестьян Воронежской губернии в конце XIX - начале XX вв. Ежегодник по аграрной истории Восточной Европы. 1: 253-268.

8. Карпачев М.Д. 2016. Русская крестьянская община и государство: социальные истоки конфликта в начале XX в. Ежегодник по аграрной истории Восточной Европы. 1: 283-297.

9. Колупаев А.А. 2015. Трудовые ресурсы Курской деревни в годы революционных событий 1917 года и гражданской войны. Известия Юго-Западного государственного университета. Серия История и право. 4 (17): 137-145.

10. Кудинова Ю.В. 2011. Положение крестьянства Воронежской губернии в период между двумя русскими революциями (1908-1916 гг.). Научные ведомости БелГУ, Серия История. Политология. Экономика. Информатика. 13 (108). Вып. 19: 146-149. 
11. Ларина О.Г., Трусова Н.С. 2017. Исторические аспекты развития налогообложения в XIX-XX веках (на примере Курской губернии). Известия Юго-Западного государственного университета. Серия История и право. 7, 1 (22): 6-14.

12. Николашин В.П. 2013. Социализация земли и «устоявшийся порядок» общинных переделов в Задонском уезде Воронежской губернии. Тамбов: Грамота, 2 (69): 121-124.

13. Николашин В.П. 2019. Поземельные конфликты в начальный период советской власти: от противостояния общин к борьбе крестьян с коллективными хозяйствами и комбедами. История: факты и символы. 3 (20): 116-125.

14. Перепелицын А.В., Фурсов В.Н. 2008. Особенности земельных отношений крестьян Центрального Черноземья в 60-90-е годы XIX века. Научные ведомости БелГУ. 10 (50): 94-100.

15. Перепелицын А.В. 2015. Общинное землевладение и землепользование в центральночерноземных губерниях России в конце XIX - начале XX вв. 4 (27): 106-110.

16. Поуездные итоги Всероссийской сельскохозяйственной и поземельной переписи 1917 г. по 57 губерниям и областям. Исторические материалы. Официальный сайт. URL: http://istmat.info/files/uploads/29782/sh_perepis_1917_-2.pdf (дата обращения: 8 февраля 2020).

17. Слепнёв И.Н. 2006. Об интенсификации традиционной практики земледелия в Центрально-Черноземном регионе. В кн.: Динамика и темпы аграрного развития России: инфраструктура и рынок. Материалы XXIX сессии Симпозиума по аграрной истории Восточной Европы. Орел: 264-272.

18. Чуркин М.К. 2006. Об особенностях аграрного кризиса в центрально-черноземных губерниях европейской России и возможных путях его преодоления во второй половине XIX - начале ХX вв. 1 (52): 29-37.

19. Чуркин М.К. 2016. Регион-«донор» - регион-«реципиент»: природно-географический фактор и его влияния на крестьянское хозяйство в местах выхода и водворения переселенцев черноземного центра России (вторая половина XIX - начало XX в.). Вестник Омского университета. Серия «Исторические науки». 2(10): 56-65.

\section{References}

1. Bezgin V.B. 2017. Krest'janskij «mir»v revoljucii 1917 goda (na materialah Tambovskoj gubernii) [Peasant «World» in the revolution of 1917 (based on the materials of the Tambov province)]. Ezhegodnik po agrarnoj istorii Vostochnoj Evropy. 1: 160-168 (in Russian).

2. Bespalov S.V. 2018. Agrarnyj krizis v Rossii konca XIX veka: vneshne- i vnutrijekonomicheskoe izmerenija. Obshhestvo i vlast' v imperatorskoj Rossii, SSSR i sovremennoj Rossijskoj Federacii [The agrarian crisis in Russia at the end of the XIX century: external and internal economic dimensions. Society and power in Imperial Russia, the USSR, and the modern Russian Federation]. 297-309 (in Russian).

3. Gatilov Je.V., Nikolashin V.P. Pozemel'nye konflikty Chernozem'ja nachal'nogo sovetskogo perioda 1917-1920 gg. [Land conflicts of the black earth region of the initial Soviet period of 1917-1920]. Klio. 2019. 12 (156): 104-121 (in Russian).

4. Esikov S.A. 2007. Krest'janskoe zemlevladenie i zemlepol'zovanie v Tambovskoj gubernii v poreformennoe vremja (1861-1905 gg.). Istoriko-pravovoe issledovanie [Peasant land ownership and land use in the Tambov province in the post-reform period (1861-1905). Historical and legal research]. $\mathrm{SPb}$., Nestor, 189 (in Russian).

5. Esikova M.M. 2009. Agrarnyj krizis konca XIX - nachala HH veka [Agricultural crisis of the late XIX - early XX century]. Vestnik Saratovskogo gosudarstvennogo social'no-jekonomicheskogo universiteta. 3 (27): 230-233 (in Russian).

6. Zhirov N.A. 2017. Krest'janskoe zemlevladenie v Orlovskoj gubernii na rubezhe $\mathrm{XIX}-\mathrm{XX}$ vv. [Peasant land ownership in the Orel province at the turn of the XIX-XX centuries]. Ezhegodnik po agrarnoj istorii Vostochnoj Evropy. 1: 99-104 (in Russian).

7. Karpachev M.D. 2014. Finansovye povinnosti krest'jan Voronezhskoj gubernii v konce XIX - nachale XX vv. [Financial duties of farmers of the Voronezh province in the late XIX - early XX centuries]. Ezhegodnik po agrarnoj istorii Vostochnoj Evropy. 1: 253-268 (in Russian).

8. Karpachev M.D. 2016. Russkaja krest'janskaja obshhina i gosudarstvo: social'nye istoki konflikta $v$ nachale XX v. [The Russian peasant community and the state: the social origins of the conflict in the early twentieth century]. Ezhegodnik po agrarnoj istorii Vostochnoj Evropy. 1: 283-297 (in Russian).

9. Kolupaev A.A. 2015. Trudovye resursy Kurskoj derevni v gody revoljucionnyh sobytij 1917 goda i grazhdanskoj vojny [Labor resources of the Kursk village during the revolutionary events of 
1917 and the civil war]. Izvestija Jugo-Zapadnogo gosudarstvennogo universiteta. Serija Istorija i pravo. 4 (17): 137-145 (in Russian).

10. Kudinova Ju.V. 2011. Polozhenie krest'janstva Voronezhskoj gubernii v period mezhdu dvumja russkimi revoljucijami (1908-1916 gg.) [The situation of the peasantry of the Voronezh province in the period between the two Russian revolutions (1908-1916)]. Nauchnye vedomosti BelGU, Serija Istorija. Politologija. Jekonomika. Informatika. 13 (108). Vyp. 19: 146-149 (in Russian).

11. Larina O.G., Trusova N.S. 2017. Istoricheskie aspekty razvitija nalogooblozhenija $\mathrm{v}$ XIX-XX vekah (na primere Kurskoj gubernii) [Historical aspects of taxation development in the XIX-XX centuries (on the example of Kursk province)]. Izvestija Jugo-Zapadnogo gosudarstvennogo universiteta. Serija Istorija i pravo. 7, 1 (22): 6-14 (in Russian).

12. Nikolashin V.P. 2013. Socializacija zemli i «ustojavshijsja porjadok» obshhinnyh peredelov v Zadonskom uezde Voronezhskoj gubernii [Socialization of the land and the «established order» of communal divisions in the Zadonsky uyezd of the Voronezh province]. Tambov: Gramota, 2 (69): 121-124 (in Russian).

13. Nikolashin V.P. 2019. Pozemel'nye konflikty v nachal'nyj period sovetskoj vlasti: ot protivostojanija obshhin k bor'be krest'jan s kollektivnymi hozjajstvami i kombedami [Land conflicts in the early period of Soviet power: from the opposition of communities to the struggle of peasants with collective farms and kombeds]. Istorija: fakty i simvoly. 3 (20): 116-125 (in Russian).

14. Perepelicyn A.V., Fursov V.N. 2008. Osobennosti zemel'nyh otnoshenij krest'jan Central'nogo Chernozem'ja v 60-90-e gody XIX veka [Features of land relations of peasants of the Central black earth region in the 60-90-ies of the XIX century]. Nauchnye vedomosti BelGU. 10 (50): 94-100 (in Russian).

15. Perepelicyn A.V. 2015. Obshhinnoe zemlevladenie i zemlepol'zovanie v central'nochernozemnyh gubernijah Rossii v konce XIX - nachale XX vv. [Communal land ownership and land use in the Central black earth provinces of Russia in the late XIX - early XX centuries] 4 (27): 106-110 (in Russian).

16. Pouezdnye itogi Vserossijskoj sel'skohozjajstvennoj i pozemel'noj perepisi 1917 g. po 57 gubernijam i oblastjam [County results of the all-Russian agricultural and land census of 1917 for 57 provinces and regions] Istoricheskie materialy. Oficial'nyj sajt. URL: http://istmat.info/files/uploads/29782/sh_perepis_1917_-2.pdf (data obrashcheniya: 8 fevralya 2020) (in Russian).

17. Slepnjov I.N. 2006. Ob intensifikacii tradicionnoj praktiki zemledelija v Central'noChernozemnom regione [On the intensification of traditional farming practices in the Central black earth region]. V kn.: Dinamika i tempy agrarnogo razvitija Rossii: infrastruktura i rynok. Materialy XXIX sessii Simpoziuma po agrarnoj istorii Vostochnoj Evropy. Orel: 264-272 (in Russian).

18. Churkin M.K. 2006. Ob osobennostjah agrarnogo krizisa v central'no-chernozemnyh gubernijah evropejskoj Rossii i vozmozhnyh putjah ego preodolenija vo vtoroj polovine XIX - nachale XX vv. [On the features of the agrarian crisis in the Central black earth provinces of European Russia and possible ways to overcome it in the second half of the XIX - early XX centuries]. 1 (52): 29-37 (in Russian).

19. Churkin M.K. 2016. Region-«donor»-region-«《recipient»: prirodno-geograficheskij faktor i ego vlijanija na krest'janskoe hozjajstvo $\mathrm{v}$ mestah vyhoda i vodvorenija pereselencev chernozemnogo centra Rossii (vtoraja polovina XIX - nachalo XX v.) [The region of «donor» - region-〈rrecipient»: natural-geographical factors and its impact on the farm in the places out and interned persons Chernozem black earth region of Russia (second half of XIX - beginning of XX century)] Vestnik Omskogo universiteta. Serija «Istoricheskie nauki». 2 (10): 56-65 (in Russian).

\section{ИНФОРМАЦИЯ ОБ АВТОРЕ}

Гатилов Эдуард Вячеславович, кандидат исторических наук, доцент кафедры истории, теории государства и права Липецкого государственного технического университета, г. Липецк, Россия

\section{INFORMATION ABOUT THE AUTHOR}

Eduard V. Gatilov, candidate of historical sciences, Associate Professor, Department of History, Theory of State and law, Lipetsk State Technical University, Lipetsk, Russia 